\title{
Migrant mothers' creative interventions into racialized citizenship
}

\section{Umut Erel, Tracey Reynolds \& Erene Kaptani}

To cite this article: Umut Erel, Tracey Reynolds \& Erene Kaptani (2018) Migrant mothers' creative interventions into racialized citizenship, Ethnic and Racial Studies, 41:1, 55-72, DOI: 10.1080/01419870.2017.1317825

To link to this article: https://doi.org/10.1080/01419870.2017.1317825

\section{(2) 2017 The Author(s). Published by Informa UK Limited, trading as Taylor \& Francis Group

Published online: 18 May 2017.

\section{Submit your article to this journal $\pi$}

\section{Џll Article views: 463}

\section{Q View related articles $\widetilde{ }$}

View Crossmark data \lceil

4 Citing articles: 1 View citing articles 


\title{
๖ OPEN ACCESS
}

Check for updates

\section{Migrant mothers' creative interventions into racialized citizenship}

\author{
Umut Erel (D) ${ }^{a}$, Tracey Reynolds (D) ${ }^{b}$ and Erene Kaptani ${ }^{\mathrm{a}}$

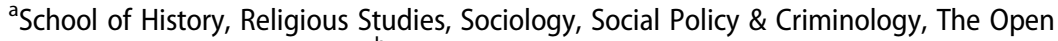 \\ University, Milton Keynes, UK; ${ }^{b}$ Department of History, Politics and Social Sciences, University \\ of Greenwich, London, UK
}

\begin{abstract}
Racialized migrant mothers are often cast as marginal to theoretical and political debates of citizenship, yet by taking seriously the contributions to cultural and caring citizenship they make, we challenge the racialized boundaries of citizenship. Drawing on theories of enacting citizenship, that is, challenging hegemonic narratives of who can legitimately claim to contribute to citizenship, we explore migrant women's mothering through participatory theatre methods. Through analysis of participatory action research (PAR) with migrant mothers in London, we emphasize the significance of embodied and affective meanings for challenging racialized citizenship. The theatre methods allow participants to develop collective subjugated knowledges challenging racialized, gendered and classed stratifications of rights, burdens and privileges of caring citizenship. This draws attention to the important role of creativity of the self as an aspect of both cultural and care work for understanding racialized migrant mothers' citizenship.
\end{abstract}

ARTICLE HISTORY Received 22 February 2016; Accepted 4 April 2017

KEYWORDS Race; family; mother; citizenship; migration; creative participatory theatre methods

\section{Introduction}

In January 2016, David Cameron, the former UK Prime Minister, declared, "We won't let women be second-class citizens. Forcing all migrants to learn English and ending gender segregation will show we're serious about creating One Nation" (The Times 18 January 2016). His argument that a large proportion of female migrants, Muslim women in particular, lacked the English language skills to engage with British values and culture, sparked heated debates, nationally and internationally. Cameron suggested that these women's lack of English skills was a key factor enabling their children's potential 
radicalization, disengagement from British life and involvement in terrorism. It is interesting to note how Cameron's analysis adopted the familiar dual trope of Muslim women as on the one hand in need of protection by the British state against their supposedly oppressive patriarchal communities. Yet on the other hand, in their capacity as mothers, Muslim women were portrayed as a threat to social cohesion and the security of the nation. Cameron's article slipped between portraying the women as "Muslim" South Asian and "recent migrants", demonstrating how recent discourses of new migration in the UK reproduce contemporary modes of racialization by simultaneously targeting long settled migrant communities, asylum seekers, Muslims, new migrants and other minority ethnic groups as the "enemies within and without our borders" (Redclift 2014, 579). Of course, Cameron's statement has not gone uncontested. One criticism has been the conflation of settled migrants with new migrants, in order to create a potent tool for questioning the ability of migrant and racialized citizens to fully belong and participate in the nation (Reynolds, Erel, and Kaptani forthcoming). Another example of contestation was a Twitter campaign by Muslim women photographing themselves with various statements, contesting Cameron's construction of victimized Muslim women who are outsiders to citizenship (\#traditionallysubmissive 2015). Significantly, this counter-discourse underlined Muslim women's contribution to the nation through their paid work as health or education workers or volunteers as well as other professional and cultural skills. One pervasive element of these self-representations is an emphasis on these women's ability to combine all of these citizenly contributions with being mothers (cf. Reynolds and Erel 2016).

This controversy is one instance of the contestations of migrant mothers' racialized citizenship. By racialized citizenship we mean cultural and political processes of constructing citizenship which deploy a social constructionist approach to "race" This recognizes racialization as a political project rooted in colonialism and imperialism drawing on biological and cultural difference and hierarchies. Racial boundaries of citizenship are performed through ideas, practices and institutions that "have consequences for those who are defined by them, in terms of choices, opportunities and resources" (Kibria, Bowman, and O'Leary 2013,4). Racialized migrant mothers are often viewed as transmitting traditional, ethnically specific values and cultural resources to their children. This has prompted researchers and policy makers to debate the ways in which migrant mothers' cultural orientation aids or hinders their children's integration into the UK (Ganga 2007; Gedalof 2009; Henry 2007; Hinsliff 2002; Tsolidis 2001). Yet, we suggest that another research question is more productive: to what extent do the contributions migrant women make through their mothering practices reframe our understandings of citizenship? Our approach does not aim to legitimize an alternative "mothering pathway" for migrants to be granted state recognition as useful citizens. Instead, we 
suggest that an understanding of citizenship which takes migrant mothers' practices as a starting point can critique the ways in which both state and everyday cultures are producing racialized, limited notions of citizenship and thereby distorting the representation of migrant mothers.

Our analysis begins by looking at how migrant mothers are enacting citizenship (Isin 2008), with a review of how migrant mothers' cultural and caring work can be framed as a citizenship practice. By doing so, we challenge and rupture hegemonic narratives of racialized citizenship. Drawing on this theoretical approach we show how migrant mothers assert citizenship and fill it with social meaning. We also explore participatory theatre methods' potential to highlight such acts of citizenship. We demonstrate through the use of participatory theatre methods how racialized and gendered citizenship is embodied and enacted. A central argument in this is that research needs to pay more attention to the interrelationship between cultural citizenship, creativity of the self and care as a citizenship practice.

\section{Mothering and racialized citizenship}

Citizenship involves contradictory processes encompassing inclusionary processes of redistribution of resources, as well as exclusionary processes of boundary making. The criteria for inclusion and exclusion are legally regulated through citizenship and naturalization policies and immigration regimes. However, in everyday life, as well as in political and legal arenas, these criteria are subject to contestations (Turner 2008). While citizenship is often understood as mainly about formal rights and duties, here we explore its wider sociological meanings. Through the concept of "enacting citizenship" (Isin 2008) which foregrounds transformative and creative acts of citizenship rather than the status or habitus of existing citizenship practices - we focus our analysis on the potential of acts to rupture given definitions of the political community and narratives of citizenship.

Migrant women's citizenship practices are realized on multiple scales: from the intimate sphere of family and friends, to the local, the national, transnational and the supra-national (Erel 2011b). In all of these sites migrant women are at once subject to regulations and take part in struggles over recognition, rights and entitlements. The nation-state continues to be an important actor in allowing migrant women's access to the territory and regulating legal, social and political rights (Lonergan 2015). Racialized migrant women, in particular, are often denied recognition as legitimate members of the society they live in. Their belonging to the nations of residence is seen as tenuous, and their social positioning as racialized, gendered "Other" mean that they are cast as "incompetent citizens" with inadequate cultural capital and relegated to low skilled, low paid jobs with minimum legal protection (Reynolds, Erel, and Kaptani forthcoming). 
While feminist debates regarding the ethics of care (e.g. Tronto 2013) acknowledge that unpaid care in the home should be seen as a citizenship practice, it is oftentimes undervalued, despite its constitutive contribution to social welfare. Migrant mothers who transgress national and racialized boundaries are symbolically positioned as potentially polluting the reproduction of the nation (Ahmed 2004; Lentin 2003; Tyler 2010). Indeed, racialized migrant women, as bearers of a culture of origin, are often constructed in policy and public debates as hindering their children's integration (e.g. Henry 2007; Hinsliff 2002). Yet, empirical research shows that migrant women's mothering practices actively and sometimes creatively intertwine change and the transmission of tradition (Ganga 2007; Gedalof 2009; Tsolidis 2001). This is often part of migrant mothers' strategies to help their children's social and cultural mobility in the new country of residence (McLaren and Dyck 2004) while trying to help their children to develop strategies to cope with and address racism (Erel and Reynolds 2014; Reynolds 2005). This involves culture work, that is migrant women engage with social and cultural practices of the country in which they live, as well as the countries they come from, to form and transform their own and their children's ethnic and cultural identifications. Another component is that they select specific cultural forms and resources to transmit to their children, re-constructing notions of family, sometimes across ethnic and transnational boundaries (Erel 2009; Erel 2011a; Reynolds and Zontini 2014). Furthermore, mothers' negotiate with their children and significant others about the meanings and ethnic and racialized inflections of these cultural practices (Erel 2009; Reynolds, Erel, and Kaptani forthcoming). This culture work is not simply a reconstitution of ethnically specific cultural resources in a new context. Instead, migrant mothers engage in negotiations over the meanings of specific cultural forms, and they create new cultural forms for doing intergenerational and care work (cf. Kofman and Raghuram 2015). In a context where the cultural practices of racialized mothers are devalued, their mothering and care work that enables them to resist racism gains a political dimension of an act of citizenship (Hill-Collins 1990; Kershaw 2010). On one hand, this culture work of mothering is political as it challenges racist institutions and practices, on the other hand, it is part of racialized migrant women's rights claims of cultural citizenship involving "a right to full cultural participation and undistorted representation" (Pakulski 1997, 83). While culture is often equated to ethnic identity, it is important to go beyond such reductionism and conceptualize cultural citizenship as anchored in a recognition of the potential creativity of the self, an example of this is our participatory theatre work with a group of migrant mothers. 


\section{Creative methods for enacting citizenship}

This article draws from our project using participatory theatre methods with a group of twenty migrant mothers, which took place in London, U.K. over a period of seven months (February-August 2014). We began with a series of eight weekly three hour-long theatre workshops, using techniques of Playback (Fox 1994) and Forum Theatre, as part of Boal's Theatre of the Oppressed (Boal 1979). The sessions of "Playback" theatre on which we focus here, involved the participants sharing their stories, which are then acted out by professional actors. According to Kaptani and Yuval-Davis (2008), the performance taking place in the theatre allows participants to see themselves and their interactions with others in a way that creates more reflexive distance than is possible in everyday life. Playback requires a relationship of trust and reciprocity of sharing experiences. It produces meaning by building a triangular conversation between actors, individual tellers and the group of participants. Narratives of individual tellers often relate to each other, elaborating on a particular theme, perhaps refining particular themes, perhaps showcasing alternative or contradicting experiences (Kaptani and Yuval-Davis 2008). In terms of forum theatre, the framework and set of techniques is based on the principles of collective empowerment and emancipation. Boal termed the participating audience member spect-actor, for they are not merely spectators or actors but practicing elements of both roles simultaneously. In a series of workshops participants construct dramatic scenes of their choice and then show them to the other participants, who intervene by taking the place of the protagonist and suggesting better strategies for changing the course of action. When participants intervene in the scene to change the course of action, forum theatre becomes not only a critical site of negotiation, but a site of active citizenship, collective mobilization and empowerment by migrant women experiencing marginalization and inequalities in U.K. society. In particular, in our study participatory theatre created a collective space allowing for the creativity of self, challenging narrow representations of migrant mothers (Erel, Reynolds, and Kaptani 2017). In this sense then the workshops constituted acts of cultural citizenship where mothers claimed a "right to full cultural participation and undistorted representation" (Pakulski 1997, 83).

A snowballing technique was employed to recruit our participants through the networks of a health organization, and included mothers from diverse ethnic and racial backgrounds, including Polish, Congolese, Somali, Turkish, Kurdish, Lithuanian mothers. The participants were not a pre-existing group, though some knew each other previously. The theatre workshops therefore presented the mothers with the opportunity to meet others from different ethnic backgrounds and with a range of migration experiences. Indeed, the participants' migration trajectories included family migrants, refugees and 
labour migrants. As researchers, we were also positioned within the social realities of racialized citizenship. The research team all hold higher educational degrees and are employed by universities, which positioned us as advantaged in social class and educational terms. However, we also shared some experiences and characteristics with the research participants. We are all mothers of young children, two of us are migrants (European migrants from both Greece and Turkish from Germany) and do not hold British citizenship. The third member of the research team is second generation black-British, the offspring of Caribbean migrant parents. We have experienced racialization and positioning as migrant Other in varying degrees and contexts and these differentiated personal experiences were useful in some instances, such as providing interpreting skills during the workshops and establishing rapport. Yet, we suggest that it was not simply our social location, but also our political values (Yuval-Davis 2011) and a broadly conceived research question "What is it like to be a migrant mother in London" which allowed the theatre workshops to function not simply as another incitement to migrant women to prove their "usefulness" to British society, but to explore their own desires for social transformation.

Scenes from the workshops and the performance at the end of project conference can be accessed on the project website (http://www.open.ac.uk/ socialsciences/migrant-mothers/participatory-theatre/). The theatre workshops were followed up by individual interviews to probe the methodological process and substantive issues that arose during the workshops. Data from all of these methods are analysed in later sections of the article.

It is important to highlight here the connections between methodology and theory. As noted above, the project draws on theories of enacting citizenship to explore how migrant mothers challenge hegemonic narratives of who counts as legitimately belonging to the nation. These theories have been used to look at migrants' struggles to claim rights and constitute themselves as political subjects, through unexpected public political acts (e.g. Nyers 2008). By bringing in a methodology that embraces principles of participatory action research, the project further elaborates these theories on the basis of the principles of producing shared knowledge with the participants; valuing all voices; producing and exchanging new knowledge which is interventionist. In this sense, the project sought to "develop purposeful knowledge leading to social change" (O'Neill, Wood and Webster 2004; also Erel, Reynolds, and Kaptani 2017). The participatory theatre methods address the question of how migrant mothers make rights claims and how they rupture ideas of who can constitute a legitimate citizen.

Working with a participatory theatre researcher/arts therapist, we encouraged the migrant mothers to perform with their bodies and voices particular scenes which are meaningful in their experience of caring and cultural citizenship. The theatre processes of sharing, being allowed to "mess about" through 
communication beyond writing and speaking starkly contrasted the practice of this research with the institutional practices of exclusion. The participants' everyday experiences of their gendered, racialized bodies entering institutions and public spaces where they were ignored or "not welcomed" were thematized. The creative ways in which the participants used participatory theatre constituted an enactment of citizenship: they were ready to improvize, and find "solutions"; their bodies were active and not "docile or dependent" (as mainstream discourses portray them) bridging among different conflictual parties, and making rights claims. Drawing on Boal's principles of the theatre of the oppressed, we understand these performative enactments not only as an artistic expression of their experiences but also as "rehearsals" for enacting change in the social world. In this sense, the methodology aims to grasp the problem that migrant mothers' caring and cultural work is often conceptualized as private, individualized and not political because it engages with mundane, repetitive everyday activities. Yet, we argue that making the meanings, conflicts and acts of resistance inherent in these mothering practices visible and an object of collective reflection and knowledge, in itself constitutes an act of citizenship and speaks to contemporary methodological concerns of engaging social life by connecting artistic, lay and sociological ways of knowing (Puwar and Sharma 2012). The value of creative methods and the collaboration with a theatre practitioner lies in the way that artistic "representations of migrants" lived experiences can be transformative, providing recognition, voice, ... such "border crossings' can enrich our theoretical work" (O'Neill and Hubbard 2010, 48). The theatre methods allowed us to engage migrant mothers in the production of knowledge on their own practices of mothering, reframing these as activist interventions into citizenship and validating their own experiences, as well as challenging the denigration of their caring and cultural citizenship, as will be elaborated below. Through their performance and engagement with forum theatre, it importantly allowed the migrant mothers to enter into a dialogue with other academics and practitioners about their lived experiences (see also Erel, Reynolds, and Kaptani 2017). The mothers were all working class, often reliant on social welfare benefits. Almost all lacked recognized educational qualifications and often had limited English language competences. This meant that in their encounters with educational and health professionals, they were often positioned as passive objects of knowledge. By training them in theatre skills and facilitating the development of reflexive, shared knowledges as a group, these mothers were enabled to bring their views and experiences into a more equal dialogue with academics and practitioners (see next section). This performative way of articulating their knowledge through theatre helped to place their subjectivity as political. This provided a meaningful challenge to other public narratives of migrant mothers as "outsiders", both oppressed and potentially a threat to social 
cohesion. In particular, these methods have helped to challenge the assertion that fluency in English is a necessary precondition for migrant women's social participation and belonging, as expounded by Cameron in the opening section of the article. Indeed, by using methods beyond language, we are able to explore how migrant mothers are claiming and practicing belonging in the everyday cultures they co-create, and despite hostile institutional climate. By using images, gestures and physical performances, participants showed their creative skills of enacting everyday practices of caring and culture work. The improvization required them to adapt to fast changing scenes, so they came up with new ideas and enactments to create coherent meanings in each scene. The theatre methods allowed the migrant mothers to build a community and articulate to each other their subjugated knowledges, and it is their embodied practices of care, both in the home and beyond as well as their embodied labour which constructs forms of belonging and function as a basis for rights claiming. These processes question the assumption that English language should normatively function as a precondition for claiming and enacting citizenship. In the following section we present some of our findings.

\section{Subjects of citizenship: developing shared knowledges}

The theatre workshops were an occasion for collective storytelling and interventions and sociality, which is particularly significant as migrant mothers often suffer from social isolation. The workshops opened up the possibility for the mothers to experience themselves as active agents creatively involved in research, which is enjoyable. This counteracts the prevalent representation of migrants as either constituting a problem or having problems.

The participants spoke of appreciating the performance based methods because they were able to take the role of "director" allowing them to become involved differently in the research process, instead of only verbalizing their experiences to a researcher during an interview (Kaptani and YuvalDavis 2008). In this project, many of the participants did not have the linguistic or cultural capital to fluently articulate their experiences in English. Many did not have command of the correct grammar or vocabulary. Their lack of fluency put them in a position whereby it was difficult for them to claim narrative authority through the spoken word. Indeed, as Mandy, one of the few fluent English speakers remarked when reflecting on a theatre scene where a migrant mother was unable to access health services due to her lack of English language,

the women become "just stuck for words ... like things were caging in and she was stuck- trapped ... sometimes you know, this happens when you can't fight back in the same language and you become paralysed" 
The important role of language in constructing or restricting women's authority to voice their stories, experiences and knowledges became very evident when a small group of participants joined a research seminar where we showed clips of the theatre scenes. While they appreciated the opportunity to be part of the seminar, they were reluctant to speak up and did not themselves raise topics for discussion. However, as part of the discussion, one of the participants, Melek, articulated her dissatisfaction of the usual format of meetings and research projects, which was based only around "talk, talk, talk" and did not give any room for "action" Furthermore, for many migrants, including our participants, the situation of being interviewed itself is associated with specific situations under the disciplining gaze of a professional, who had the power to make far reaching decisions over their lives. Thus, interview situations were often associated with the migration process, in particular for those who had sought asylum, interactions with job centre or social security staff, assessment procedures and job interviews (Kaptani and Yuval-Davis 2008). This is one further way in which the centrality accorded to English language fluency as a precondition for full citizenship needs to be questioned. Rather than viewing English language as a competence enabling full participation as citizens, in these instances, assessments of migrants' English language skills become a vehicle for surveillance and exclusion from participation. In light of this, performative research methods, which involved the body and gave participants situational authority over their own stories and expressions were an important aspect of enabling them to claim representation of their own experiences and lives.

These participatory theatre methods shed light on how the migrant mothers' identities and positionalities are constructed as performative acts (Kaptani and Yuval Davis 2008). The performance creates a liminal space where everyday norms are suspended, the familiar is de-familiarized and multiple realities can emerge, allowing research participants to re-appropriate their narratives (Kaptani 2011). Participatory theatre has a transformative potential as performances offer a multiplicity of meaning and interpretation they contribute to the emergence of new ways of seeing and doing things. Aida reflecting on the workshops, suggested that her lack of confidence in her English meant she was initially hesitant to share her experience.

Still I try to do my best and I don't even mind to share my story with other communities because I feel like, because I [had been] suffering in silence. That day, when I start[ed] talking [...] I feel like I can talk [...] above my silence, sharing ideas with other people so I feel like free- [...] relieved. But I [had] suffer[ed] in silence for so many years, I never share[d] my story with other people- not even my people, my close parents- that day was my first ever to share my story with other different set of people. I feel so happy. I don't mind because [...] if I talk my story, someone suffer[ing] in silence like me, they might decide to share their story with others, as well. They might [gain] confidence. 
Working together over a period of two months, the participants got to know each other, and developed shared knowledges. The participatory theatre was an opportunity to share experiences with other mothers to develop solutions. For example, the women chose scenes, where they were denied access to services, be it at the doctor's surgery, at the job centre or in the hospital. The participatory theatre scenes around the topic of accessing services were found to be helpful as rehearsing how to assert their rights to enact citizenship. As Aida reflects:

[I] said "stop that" [...] because the way [the receptionist denying the patient access to the doctor] was speaking [...] was completely wrong. Then [...] I said to myself "I have to do something- why [am] I [just] sit[ting] here?" because I feel myself confident and then I have to say "do this one - this is not right" And I have to [claim] my right. If it's not right, I have to [claim] my right.

We saw the women using theatre exercises to challenge the surgery receptionist or the job centre officer as they were putting into practice policies denying them access to services. Even where racialized migrant women are entitled to access services, in practice they are often unable to claim these rights and substantiate their citizenship as they lack the power, linguistic and cultural capital to contest the behaviour of gatekeepers (cf. Lonergan 2015). The theatre scenes encouraged them to come on the "stage" one after another to try out different tactics to claim their rights.

It was wonderful. Like put yourself in the situation, what happened, because it's not everyone, you know, have the same experience. And for example if I haven't got experience in their particular situation, it makes me think, you know, what would be, what I would do with that? Because people can get information through these workshops and [...] it would be easier to tackle these problems. Like you know, sometimes people go to the hospital or to council. And they just like playing football with them, kick them out and go to someone else and after someone else to somewhere else again and so on so on so on ... (Judyta)

These processes of enacting different strategies for rights claiming, gave participants "a lot of different ideas I wasn't having before. I felt something was opening" as Gamila puts it. These shared knowledges, then can form the basis for small and larger acts of resisting their marginalization as racialized migrants.

\section{Migrant mothers as caring subjects}

Current migration regulation of non-EU migrants to the UK is bifurcated between those considered skilled migrants who attain relatively stable migration status and social rights, and those considered unskilled, whose access to residence rights, social citizenship and family rights is limited (Piper 2008). Those who are considered unskilled migrants, find employment 
particularly in jobs that involve care for the elderly, sick and children, domestic work, sex work (Kofman and Raghuram 2015). These jobs - both in formal and informal labour markets - are increasingly becoming the domain of migrants, particularly migrant women. Through this type of paid work, migrant women become pivotal for the social reproduction of their countries of residence, "maintaining and reproducing people, specifically the labouring population, and their labour power on a daily and generational basis" (Bezanson and Luxton 2006, 3). Despite their central social function, these jobs are underpaid and require long working hours. In addition many of the migrants in these jobs are undocumented or have insecure migration status. Furthermore, the informal nature of much of this employment, especially in private households, means that even where migrants have a right to reside and work in the UK, they may not be able to access work-related benefits or prove their labour market participation for the purposes of gaining a secure residence status.

While the unequal distribution of social and emotional costs of social reproduction has been highlighted for transnational families, in the context of migrant mothers with co-resident children, racialized, classed hierarchies also lead to unequal opportunities for migrant mothers' performing caring citizenship. One of the mothers, Judyta, migrated from Lithuania to London in 2004. This migration was motivated by her desire to flee her husband's domestic violence against herself and her son, as well as a wider culture of sexism, which exposed her to sexual harassment in the workplace and saw her struggling to find employment after the birth of her son. Initially she arrived by herself to try and find accommodation and employment, and after three months brought her son to join her. She remembers this initial period as "horrible" As a recent migrant she managed to access only informal jobs in restaurants, with low pay and long hours. As she worked twelve to fourteen hours a day, she was not able to give her son and older daughter the time and attention she would have liked to. This for her was epitomized in the situation where she was not able to accompany and help settle her son at school in London. Her son arrived without speaking any English and was scared to go to school by himself. Judyta came forward in the Playback session and shared her story:

What most hurt me, and to this day I remember this story, on his second day, he was bending his knee and kissing my hands, asked me "Please, please, I don't want to go to school! Please, please, mum!" he said. And I had to say "Sorry, I have to go to work, because [at] this time I was working really, really hard (...) this one really hurts me a lot.

The facilitator and Judyta decided to ask the actors to play back the moment of separation. The four actors each embodied and acted out Judyta's feelings: one actor reluctantly pushed her son to go to school, while another expressed her wish to calm and reassure her son, wishing 
she could go with him on this difficult first day. A third actor was torn in a different direction, feeling pressured by economic necessity, he kept repeating "I have to go to work, I have to go to work" while the fourth actor bent down to be eye level with the son and, showing the pain she was feeling, expressed her wish that it could be another way. Finally asking her son, and implicitly her own self, to trust that things would work out (http://www. open.ac.uk/socialsciences/migrant-mothers/participatory-theatre/ see "First Days in London" clip).

This intense emotional moment was played out in front of Judyta and the group as an exemplary moment of mothering in migration. The actors' performance gave shape to Judyta's amorphous feelings of having to fulfil both roles of economic provider and emotional care giver, under very precarious conditions and with no state or personal support system in place as a new migrant. This experience, while common to many migrant mothers, is at once highly personal and rarely shared. By bringing this experience to the group, Judyta challenged the privatization of the emotional costs of establishing economic security for a migrant family (cf. Gutiérrez Rodríguez 2007; 2010). She participated in what Baraitser (2009) conceptualizes as mothers "making things public" that is bringing to a shared, public space her experience of mothering. Drawing attention to and making public the effects of migration regimes in creating and heightening racialized and classed privileges of care, Judyta's story creatively challenges the invisibility of migrant mothers' subjectivity and thus constitutes an intervention into cultural citizenship. By sharing her experience with the group, she creatively contributed to new stories, subjectivities and conflicts to become part of a public narrative repertoire formulating a new conscience of racialized injustices of care. While the inner conflicts of mothers participating in paid work have become a part of Western narrative repertoires, these narratives often focus on normative forms of femininity marked by class and educational privileges, often implicitly constructed as a white national. On the other hand, contemporary public culture is saturated with the expectation that especially poor and migrant subjects need to prove their ability to economically provide for their families, in order to qualify as respectable citizens (Erel 2011b, Lopez Rodriguez 2010). The Playback of Judyta's story, by articulating a subjectivity and the affective dimensions of her class specific racialized citizenship, claims emotional and cultural recognition for migrant women's experiences and conflicts around mothering, in this sense enacting cultural citizenship. We suggest that the creativity of the self Judyta enacts by expressing her experiences and conflicts of care, mothering and work becomes an act of cultural citizenship. This is because she is articulating her experience as an injustice over the classed and racialized distribution of the right and resources to care. 


\section{Caring and reproductive work: a day in my life}

When the theatre facilitator asked what everyday life was like as a migrant mother in London. Zarin, a refugee from Somalia responded (with the help of her friends' translation into English), "I get up at six o'clock, after that I have a shower. I have breakfast. After that I go to work. After that I come back home, I clean my house" At this point, Zarin laughs and her friend interjects that "at home, Zarin cannot relax, because she has so many responsibilities". Zarin's day is filled with "hard work, hard work" Her paid work is in childcare. In the evenings, not only does she continue her reproductive work in her own home by cleaning and cooking, she also looks after her grandchildren while her daughter attends college. Despite all this hard work, Zarin smiles, seeing this perhaps as her best way of coping with the never-ending work of reproduction.

The actors played back this scene by showing the physical contortions of engaging in caring and reproductive work: their bodies were bent under the weight of cleaning, looking after others, while they had to stretch their arms out and jump to reach far in the hope of catching a tiny bit of "time for myself" The bodies burdened by this caring and reproductive work, were by the end of the day slumped, drained and empty. Zarin's gesture, to laugh and smile as a way of coping with this overwork was shown by the actors' final gesture: abruptly changing their exhausted facial expressions, they jump and symbolically push up the edge of their mouths into a smile. The smile, as a way of coping is as much an outcome of willpower and effort as it is a gesture of defiance.

The never-ending labour of reproduction has given way to notions of feminine, circular time, often contrasted with linear time in which a normative, male subject unencumbered by caring responsibilities, develops agency, while the repetitiveness of women's domestic and care work has been seen as impeding agency. Yet, such an approach actively misrecognizes the important function of creating stable, liveable lives that this reproductive work entails (Felski 2000). Women's close association with, and responsibilities for childbearing and rearing, as well as reproductive labour through cleaning, cooking, caring for others, have been important factors in denying them full citizenship. These tasks of social reproduction have at once been considered women's responsibility and contribution to citizenship, while at the same time binding women to the domain of the private, which has traditionally been conceptualized as the opposite of the public domain of citizenly engagement (Lister 2003; Pateman 1992).

Thus, homemaking and migrant women's reproductive work are contradictory: at once riven with the tension of privileges and oppressions, yet also potentially allowing for women's creative interventions into these very power relations. So, while feminist authors on one hand emphasize the 
gendered power relations involved in making a home, it is also important to acknowledge that care and reproductive work can entail moments of resistance and creativity (Gedalof 2009). This has been emphasized in particular with relation to racialized working class women's efforts to care for their families (Erel 2009; Hill-Collins 1991; Hooks 1991; Reynolds 2003). The playback scene reflecting Zarin's story, underlines the emotional costs of gendered, classed and racialized power relations inscribed in immigration regimes.

Zarin's experience shows the multi-layered and complex ways in which her caring work is constitutive of the social. Through her paid work in childcare, she enables the parents of the children she is working for to participate in paid employment, often seen as the key responsibility of neoliberal citizens. In her unpaid caring work, by cleaning and caring for her own family, she enables their reproduction. When she cares for her grandchildren in the evenings, she enables her adult daughter to participate in further education, in an attempt to further her skills, qualifications and choices in the labour market. So, Zarin's invisible caring and reproductive labour is not only part of her own citizenship practices as contributing economically to the society she lives in, it is also a constitutive factor for enabling the economic contribution of others: the parents of the children she cares for and her daughter.

The analysis of these two Playback scenes highlights the usefulness of participatory theatre methods for attending to the embodied and emotional aspects of migrant women's lives. Judyta's story showed a unique and particularly dramatic moment in her migration experience, crystallizing the challenges for migrant women who are incorporated in the labour market in low skill, low pay jobs, often informally, requiring long hours. This, in turn does not leave her with the time and energy to care for her own family. Indeed, "time to care" (Knijn and Kremer 1997) then becomes not a right for all, but a privilege for those with secure citizenship status and stable incomes. Zarin's story relates not to the extraordinary, but recounts the place of care and reproduction as contextualized with gendered, racialized and classed power relations in everyday life. In contrast to Judyta's story, it highlights how care for others, whether in paid work or unpaid care in the familial sphere, leaves no time to care for herself. It is in this sense that it reminds us of the importance not only of time to care, but also "a right not to care" (Finch quoted in Tronto 2012, 33), which is stratified according gender, class, race and citizenship status. Taken together, both Playback scenes underline the complex ways in which migrant mothers' care is at once an aspect of their citizenship contribution, and at the same time representative of their status as racialized and gendered citizens who cannot claim the right to choose the time to care or refuse the incitement to care for others. In this way, both Playback scenes draw our attention to different situations of unjust distribution of resources, opportunities and choices of care. 
Methodologically, this shows how the narratives produced by Playback Theatre highlight some important generative themes. In this case it is the way in which a right to choose to care for one's family members, and also the resources to care for oneself are not accessible to many working class racialized migrant mothers who are incorporated into low paid sectors of the labour market, often in reproductive spheres. The narratives in Playback are personal as the narrator talks about her own experiences, taking her lived life as a starting point to develop knowledge. Yet, Playback theatre creates a space where these personal, individual experiences can cross over into a shared, collective embodied conversation. As an individual teller shares her experiences with the group and the actors, they create a public which is supportive of their voices being heard (Plummer 2001). This public, in turn helps the teller to make sense of her experiences. In particular, the actors' embodiment and performance of the story allows the teller to validate her own experiences and encourages participants to make meaning of their lived experiences. It is in this context that forms of collective "subjugated knowledges" (Foucault 1980, 81) can emerge which challenge hegemonic narratives of rights and citizenship. These narratives are part of a creative intervention into citizenship, disrupting migrant mothers' distorted representation and in this sense is an enactment of their cultural citizenship.

\section{Conclusion}

Racialized migrant mothers in the UK are constructed in contemporary political and public debate as marginal, they are expected to prove their ability to belong by conforming to neoliberal ideals of the good citizen, involving especially their ability to contribute through paid work and to integrate themselves and their children into "British values". They are seen, in David Cameron's words as in need of being "forced" into citizenship (The Times, 18 January 2016). It is against this backdrop that we argue for a recognition of migrant mothers as challenging hegemonic notions of good citizenship. We argue that they enact citizenship through their cultural work and their caring work, both within their families and in wider society. This has been shown in particular through our research project mobilizing participatory theatre methods to enable their creative interventions into citizenship. Participatory creative methods are particularly apt to allow migrant mothers to express the complex dilemmas of racialized, classed and gendered power relations as articulated in the right to choose to care for family and also care for themselves. We highlight the emotional costs of migrant women's relegation to low paid jobs in the reproductive sector and the repercussions this has for their constitution as caring and cultural subjects. Drawing on the theoretical and methodological resources of enacting citizenship, brings to the fore racialized migrant mothers' potential to contest, through their creative participation in 
research, these injustices and contribute to the creation of alternative subjugated knowledges. These subjugated knowledges may not easily translate into verbal discourse, therefore we suggest the visual and the performative movements as moments of enactment are an important area for further study that can enhance researchers and participants' ability to challenge racialized hierarchies of citizenship. We argue that the concept of cultural citizenship, with its emphasis on the political and contested nature of cultural identities and practices, should be brought into dialogue with care as a citizenship practice. Embodied experiences and conflicts of care can be expressed through creative methods. These creative methods have a potential to highlight the injustices of rights, burdens, and privileges of care, and the ways in which this group of women challenges racialized boundaries of citizenship.

\section{Disclosure statement}

No potential conflict of interest was reported by the authors.

\section{Funding}

This work was supported by the Arts and Humanities Research Council [AH/K00591X/1].

\section{ORCID}

Umut Erel (i) http://orcid.org/0000-0001-7853-991X

Tracey Reynolds (D) http://orcid.org/0000-0002-9618-6318

\section{References}

Ahmed, S. 2004. The Cultural Politics of Emotion. New York: Routledge.

Baraitser, L. 2009. "Mothers Who Make Things Public." Feminist Review 93: 8-26.

Bezanson, K., and M. Luxton. 2006. "Introduction. Social Reproduction and Feminist Political Economy." In Social Reproduction. Feminist Political Economy Challenges Neoliberalism, edited by K Bezanson, and M. Luxton, 3-10. Montreal: McGillQueen's University Press.

Boal, Augusto. 1979. Theatre of the Oppressed. London: Pluto.

Erel, U. 2009. Migrant Women Transforming Citizenship: Life Stories from Germany. Abingdon: Ashgate.

Erel, U. 2011a. "Migrant Mothers Transmitting and Transforming Ethnic Identities." In Family, Ties and Care, edited by H. Bertram, 289-297. Opladen: Verlag Barbara Budrich.

Erel, U. 2011b. "Reframing Migrant Mothers as Citizens." Citizenship Studies 15 (6-7): 695-709.

Erel, U., and T. Reynolds. 2014. "Research Note: Black Feminist Theory for Participatory Theatre with Migrant Mothers." Feminist Review 108: 106-111.

Erel, U., T. Reynolds, and E. Kaptani. 2017. "Participatory Theatre for Transformative Social Research." Qualitative Research, 9 April, http://journals.sagepub.com/doi/full/ $10.1177 / 1468794117696029$ 
Felski, R. 2000. "The Invention of Everyday Life." New Formations 39: 15-31.

Foucault, M. 1980. "Two Lectures in Power/Knowledge." In Selected Interviews and Other Writings 1972-77, edited by Paul Hemel Rabinow, 78-108. Hempstead: Harvester Wheatsheaf.

Fox, Jonathan. 1994. Acts of Service: Spontaneity, Commitment, Tradition in the Nonscripted Theatre. Paltz: Tusitala.

Ganga, D. 2007. "Breaking with Tradition Through Cultural Continuity." Migration Letters 4 (1): 41-52.

Gedalof, I. 2009. "Birth, Belonging and Migrant Mothers: Narratives of Reproduction in Feminist Migration Studies." Feminist Review 93: 81-100.

Gutiérrez Rodríguez, E. 2007. "The 'Hidden Side' of the New Economy: On Transnational Migration, Domestic Work, and Unprecedented Intimacy Frontiers." Journal of Women Studies 28 (3): 60-83.

Gutiérrez-Rodríguez, E. 2010. Migration, Domestic Work and Affect: A Decolonial Approach on Value and the Feminization of Labour. New York: Routledge.

Henry, J. 2007. "Muslim Mums Told to Speak English at Home." Sunday Telegraph, 14 January 2007. Accessed January 14, 2007.

Hill-Collins, P. 1990. Black Feminist Thought. Knowledge, Consciousness, and the Politics of Empowerment. Boston: Unwin Hyman.

Hill-Collins, P. 1991. "The Meaning of Motherhood in Black Culture and Black MotherDaughter Relationships." In Double Stitch: Black Women Write About Mothers and Daughters, edited by Bell-Scott, 42-60. Boston: Beacon Press.

Hinsliff, G. 2002. "Speak English at Home, Blunkett Tells British Asians." The Observer, 15 September. Accessed September 15, 2002.

Hooks, Bell. 1991. Yearning: Race, Gender, and Cultural Politics. London: Turnaround.

Isin, E. F. 2008. "Theorizing Acts of Citizenship." In Acts of Citizenship, edited by E. F. Isin, and G. M. Nielsen, 15-43. London: Zed Books.

Kaptani, Erene. 2011. "Embodied Methods and Acts of Power." Workshop Presentation at Open University, 23 June 2011.

Kaptani, E., and N. Yuval-Davis. 2008. "Participatory Theatre as a Research Methodology: Identity, Performance and Social Action among Refugees." Sociological Research Online 13 (5): 2. http://www.socresonline.org.uk/13/5/2.html doi:10.5153/sro.1789.

Kershaw, P. 2010. "Caregiving for Identity Is Political: Implications for Citizenship Theory." Citizenship Studies 14 (4): 395-410.

Kibria, N., C. Bowman, and M. O'Leary. 2013. Race and Immigration. Cambridge: Polity.

Knijn, T., and M. Kremer. 1997. "Gender and the Caring Dimension of Welfare States: Toward Inclusive Citizenship." Social Politics: International Studies in Gender, State \& Society 4 (3): 328-361.

Kofman, E., and P. Raghuram. 2015. Gendered Migrations and Global Social Reproduction. Palgrave: Houndmills.

Lentin, R. 2003. "Pregnant Silence: (En)gendering Ireland's Asylum Space." Patterns of Prejudice 37 (3): 301-322.

Lister, R. 2003. Citizenship: Feminist Perspectives. London: Palgrave Macmillan.

Lonergan, G. 2015. "Migrant Women and Social Reproduction under Austerity." Feminist Review 109: 124-145.

Lopez Rodriguez, M. 2010. "Migration and a Quest for 'normalcy'. Polish Migrant Mothers and the Capitalization of Meritocratic Opportunities in the UK." Social Identities 16 (3): 339-58.

McLaren, A., and I. Dyck. 2004. "Mothering, Human Capital, and the 'Ideal Immigrant'." Women's Studies International Forum 27: 41-53. 
Nyers, P. 2008. "No One Is Illegal Between City and Nation." In Acts of Citizenship, edited by E. Isin and M. Nielsen Greg, 160-181. London: Zed Books.

O'Neill, M., and P. Hubbard. 2010. "Walking, Sensing, Belonging: Ethno-Mimesis as Performative Praxis." Visual Studies 25 (1): 46-58.

O'Neill, M., P. Woods, and M. Webster. 2004. "New Arrivals, Participatory Action Research, Imagined Communities and Social Justice." Journal of Social Justice 32 (1): 75-89.

Pakulski, Jan. 1997. "Cultural Citizenship." Citizenship Studies 1 (1): 73-86.

Pateman, C. 1992. "Equality, Difference, Subordination: The Politics of Motherhood and Women's Citizenship." In Beyond Equality and Difference: Citizenship, Feminist Politics, Female Subjectivity, edited by G. Bock, and S. James, 17-31. London: Routledge.

Piper, N. 2008. "International Migration and Gendered Axes of Stratification." In New Perspectives on Gender and Migration: Livelihood, Rights and Entitlements, edited by N. Piper, 1-18. London: Routledge.

Plummer, K. 2001. Documents of Life 2: An Invitation to a Critical Humanism. London: Sage.

Puwar, N., and S. Sharma. 2012. "Curating Sociology." The Sociological Review 60: 40-63. doi:10.1111/j.1467-954X.2012.02116.x.

Redclift, V. 2014. "New Racisms, New Racial Subjects? The Neo-liberal Moment and the Racial Landscape of Contemporary Britain." Ethnic and Racial Studies 37 (4): 577-588. doi:10.1080/01419870.2014.857032.

Reynolds, T. 2003. "Black to the Community: An Analysis of 'Black' Community Parenting in Britain." Journal of Community, Work and Family 6 (1): 29-45.

Reynolds, T. 2005. Caribbean Mothering: Identity and Experience in the UK. London: Tufnell Press.

Reynolds, T., and U. Erel. 2016. "Migrant Mothers Creative Interventions into Citizenship." Open Democracy, 22 January https://www.opendemocracy.net/traceyreynolds-umut-erel/migrant-mothers-creative-interventions-into-citizenship.

Reynolds, T., U. Erel, and E. Kaptani. Forthcoming. "Migrant Mothers: Performing Belonging and Participation across Private/Public Boundaries." Families, Relationships, Societies.

Reynolds, T., and E. Zontini. 2014. "Bringing Transnational Families from the Margins to the Centre of Family Studies in Britain." Families, Relationships and Societies 3 (2): 251-268.

Tronto, J. 2012. "Democratic Care Politics in an Age of Limits." In Global Variations in the Political and Social Economy of Care: Worlds Apart, edited by Shahra Razavi, and Silke Staab, 29-42. London: Routledge.

Tronto, J. C. 2013. Caring Democracy. Markets, Equality, and Justice. New York: NYU Press.

Tsolidis, G. 2001. "The Role of the Maternal in Diasporic Cultural Reproduction-Australia, Canada and Greece." Social Semiotics 11 (2): 193-208.

Turner, B. 2008. "Citizenship, Reproduction and the State: International Marriage and Human Rights." Citizenship Studies 12 (1): 45-54.

Tyler, I. 2010. "Designed to Fail: A Biopolitics of British Citizenship." Citizenship Studies 14 (1): 61-74.

Yuval-Davis, N. 2011. The Politics of Belonging. London: Sage. 